\title{
Competence value emersion: a key to sound practices in entrepreneurial finance. From ' $Q$ ' to ' $T$ ' ratios in the North-Eastern Italian experience
}

\author{
Guido Max Mantovani \\ Department of Management, \\ $\mathrm{Ca}$ ' Foscari Challenge School, \\ Ca' Foscari University, \\ Dorsoduro 3246, I-30123 Venice, Italy \\ and \\ H.E.R.M.E.S. Universities, \\ c/o Ecole de Management de Strasbourg, \\ 61 Avenue de la Forêt Noire, 67000 Strasbourg, France \\ Email: gmanto@unive.it
}

\begin{abstract}
The determinants of the value of the entrepreneurial competences and behaviour are examined. The study reveals that time is the link between marginal productivities of the capital assets and that of the human competences. The successful entrepreneur behaves in order to give marketability to skills, riding a cycle that transforms them into a corporate hallmark. We provide a detailed description of a methodology to measure the 'competence value' and to compare it against standard goodwill estimations. Results of empirical analysis over a sample made of more than 3,000 Italian companies show that the proposed Intato-T-ratio is a stronger estimator than the widely diffused Tobin-Q-ratio. Allocating investments according to the competence value can exploit immediately $51 \%$ of hidden values and allow higher growth rates during an entrepreneurial cycle lasting 13 years on average. Aborting competence value in credit allowances procedures will impact dramatically on SMEs after the adoption of Basel-3 agreements.
\end{abstract}

Keywords: valuation; incomplete markets; small and medium enterprise; SME; entrepreneurship.

Reference to this paper should be made as follows: Mantovani, G.M. (2015) 'Competence value emersion: a key to sound practices in entrepreneurial finance. From 'Q' to 'T' ratios in the North-Eastern Italian experience', Int. J. Entrepreneurship and Small Business, Vol. 24, No. 3, pp.383-416.

Biographical notes: Guido Max Mantovani teaches corporate finance and banking at Ca' Foscari University of Venice, mainly in the Treviso Campus and as Dean of the Ca' Foscari Challenge School. He is a Guest Professor of Entrepreneurial Finance at Ecole de Management de Strasbourg and previously taught in Bocconi University of Milan and Harvard University (Summer Program). His main research fields are entrepreneurial finance, rating systems and corporate risk management. As President of HERMES-Universities Association and the Teofilo Intato Foundation, he spread his competence both in academics and practioneers' activities. 
This paper is a revised and expanded version of a paper entitled 'Competence value emersion: a key to sound practices in entrepreneurial finance. From ' $Q$ ' to ' $T$ ' ratios in the North-Eastern Italian experience' presented at Academy of Entrepreneurial Finance, 2011 Annual Meeting, UCLA, Los Angeles (CA), 23 September 2011.

\section{Introduction}

The full adoption of techniques based on the so-called 'Basel-II agreement' has dramatically changed the funding procedures used by financial intermediaries in credit allowances. As a consequence, small and medium enterprises (SMEs) are severely hit by a size-specific credit crunch as a consequence of their higher credit risk highlighted by standard financial analysis procedures (Brav, 2009). Entrepreneurial challenges are hit even more, due to their higher concentration of investment in intangible assets, growth opportunities and, most of all, skills embedded in their 'human capital' (Kerins et al., 2004). Both debt and equity capitals divert from entrepreneurial finance transactions for their low return-to-risk ratios, mainly due to excess risk, at least as it is perceived through the investors' risk aversion level. This financial problem is direct consequence of value concept: the best practices in value measurement are focused on capital assets instead of human competences. In fact, to estimate the latters you should require a model to detect the financial contribution of human behaviour.

Despite the Basel regulating framework aimed to provide protection for the invested capitals by reducing risk, its true final achievement was to reduce the amount of credit flows. This is why the announcement of Basel-III standards is often depicted as the 'final countdown' to the end of financial support to entrepreneurial finance. No one is able to determine, with a certain authority, if the above depicted financial shortage is mainly a consequence of the methodologies adopted in the financial industry (i.e., techniques of financial analysis), or that of the concept of entrepreneurial business valuation (i.e., to the value-assessment practices). At present, it must be recognised that neither the professionals nor the academics have found and undisputable answer to this tricky trade-off. However, both tend to blame each other for the failure to solve the entire puzzle (Rajan and Zingales, 1995).

Clearly, the measurement of the competence value is the core of the financial puzzle made of jointly lack of enough funds and sound methodologies. This paper proposes a unique model which enables both practitioners and theoreticians to value human competence at methodological and conceptual levels.

On the methodology-side of the trade-off, the best practice in financial analysis demonstrates a kind of schizophrenia. It recognises the importance of the use of market values in the financial analysis. However, the real application made by the financial analysts suggests to use book values criteria especially for unlisted corporations. The need to strike a balance between analysis carried out on 'book values' and those referring to 'market values' remains the most difficult quest to tackle. The contribution of 
knowledge they both offer is clear, but reconciling the results emerging from the two approaches to offer appropriate solutions to businessmen is extremely difficult.

On the conceptual-side of the trade-off, on the other hand, real entrepreneurial finance usually do not detect market values due to a lack of affordable pairing groups in value benchmarking. This is because corporate finance theory requires the use of value estimation approaches based on standard/neo-classic financial models. The neo-classical financial model has a clear 'bug' for small businesses financial analysis since it misses non-emerged values due to market incompleteness (i.e., they are aborting entrepreneurship, being incomparable).

Consequently, a loop triggers: 'no measurement' means 'no assessment', which means 'no business decision/behaviour', which means 'no investment', which means 'no market value' which, finally, means 'no measurement' opportunities (Faulkender and Petersen, 2006). Our research question is: can we conceive a competence value framework to avoid the loop and to increase trust over Basel tools?

In the Italian case, the financial puzzle seems to be more complicated due to the typical structure of businesses. Small-sized companies, strong ownership control, under-capitalisation and lack of transparency in financial statements are all elements making the investigation more complex to carry out. The adopted practices use very different approaches to solve the information asymmetry that generates the above mentioned credit rationing, particularly constraining in the Italian case. This seems to be a reliable approach based on the best practices and regulations in use in the financial world. However, it does not allow us to explain the above average performance of several small business districts (e.g., the Venetian-North-Eastern area) and their long term persistence. Moreover, it cannot explain why the good performance is concentrated in rationed companies while bad debts continue to increase in balance sheets of Italian banks. Finally, as clearly detected by Kilby (1971), such an approach in standard financial practice clearly shows its limits in terms of growth opportunities even today, as is shown by macro-data on business development in Italy.

But the complexity generated by anomalies and asymmetries of the Italian case can be an exceptional work out to develop alternative approaches to entrepreneurship. These different approaches support sound practices in entrepreneurial finance transactions. The performance persistence of the Italian SMEs supports the adoption of a conceptual scheme where the strength of the economic activity is evidenced by the creation and emergence of what we call the competence value: a theme which is as fascinating as it is dangerous. Practical difficulties of transforming the competence value into market value reveals the drivers to sound entrepreneurial finance practices.

The paper is organised in the following fashion. Section 2 introduces a conceptual framework of entrepreneurial economics which is suggested to support the gaps between fair and market values. Section 3 explores the opportunities of an incomplete market approach to use contingent-claim methods to proxy the competence-value. Section 4 presents the basics of the Intato-method for competence value proxy on a sample of SMEs in the Treviso's District. Section 5 concludes along with some possible further research developments. 


\section{Skill contributions to entrepreneurial business models}

Our idea is to think about skills as a productive factor contributing to business economics (Baumol, 1968). In the entrepreneurial businesses, skills contribution to corporate economics is the key factor, typically supplied by the entrepreneur. Skills productivity is strongly joined to that of the capital used by the company (Baumol, 1993) while its level depends on the true behaviour of the entrepreneur inside the firm. Accordingly, the entrepreneur involved in SMEs is usually also a very important member of the equity owners. When this is the case, the specific conjunction of capital and skills is depicted even in the legal aspects of the firm's life (Salim, 2005). This is why "an important junction as entrepreneurs' and investors' decision do not always seem to follow traditional economic models" (Strom, foreword in Yazdipour, 2011) and even why entrepreneurial finance is related to behavioural finance.

The joint productivity of invested capital and skills is the key problem for a sound value measurement of entrepreneurial economics (Zahra, 1991). The final output (i.e., business return) is unique while inputs can be all identifiable in their nature, even if not always in their dimension. This is why it is very difficult to split the returns according to the marginal contributions of the different inputs and why the markets (both capital and job) remain incomplete. A neoclassical economic approach to entrepreneurial business is unfit for obvious reasons. Ever since the abolition of slavery, it has been possible to dissociate capital from human beings but not their competences. Thus, when entrepreneurs sell their own company shares, they are actually transferring the capital-only component of their legal title, while skills remain anyway their own property. That is why the price of shares can divert from (i.e., be lower than) their value in case of permanence of the entrepreneur inside the firm. In this second scenario the excess returns are still supported by the contribution of the entrepreneur's competences, while in post-selling scenarios no skill-contributions will exist. Skills have value per se, but do not have price until they are embedded inside the corporate organisation. True transfer of skills into assets and firms depends on true behaviour of the entrepreneur during the corporate life-cycle. The tricky topic, here, is the relation between corporate performance and overconfidence: a typical quest of applied behavioural (corporate) finance. Having a sound method to assess the value of skills could help investors to detect whether they are paying for the real or for the perceived competences in order to normalise their risk aversions.

Consolidated behavioural finance research confirms that overconfidence is a typical bias of the entrepreneurs (Busenitz, 1999; Cooper et al., 1988). Our idea is that this is due to a specific characteristic of the entrepreneurial expertise: its convertibility from an individual feature to a firm hallmark according to the true behaviour of the entrepreneur. This triggers a process of (intangible) corporate wealth capitalisation, since the know-how of the entrepreneurial skills can be spread more easily through learning experience than through market transactions (Rullani, 2004).This knowledge-economics approach suggests several applicable distinctions from the neoclassical framework, as:

1 time is no more a present value computation input but the only affordable (but redundant) means to transmit knowledge

2 business organisation is no longer a mere nexus-of-contracts but a social framework that allows individual behaviour to embed personal skills into corporate structures (including technology). 
Once the process of skill transfer to the organisation has been completed, wealth generation at competitive rates of return is due to increased productivity of corporate capital brought (only) by the injection of human competence (i.e., corporate returns are no longer person-related and consequently marginal productivity separation puzzle is dissolved). At that moment, the corporate selling-price and the entrepreneur-contingentvalue will converge being both based on the same return-to-risk expectations. There is no longer any information risk (Allen and Gale, 1994) involved. During competence spreading period, the selling-price will grow up to the going-concern-value since competences are being 'cloned' from the entrepreneurial brain into the firm structure. The corporate return-to-risk ratio is already satisfying expectations but it is hit by idiosyncratic information risk (Mantovani, 2012) due to the marginal productivity conjunction. In these situations, markets become incomplete because value exists at fair concept but not in transaction prices. Contracts are even incomplete, increasing information asymmetries and risk-premia.

We can also envisage a similar overconfidence puzzle in the typical managerial framework of the financial theory of the firm, due to very restrictive and unrealistic conditions for equilibrium (Modigliani and Miller, 1958). Undertaking a widespread ownership of the corporation and separating ownership and control means typically to entrust competences in management staff. Even in this case, consolidated research in corporate behavioural finance suggests that some categories are more exposed to this phenomena, such as top-executives (Malmendier and Tate, 2008; Ben-David et al., 2007; Hiller and Hambrick, 2005). The split of the increased wealth that is produced by managerial competences is negotiated between ownership and management through the agency contract that governs their relationships. Strong agency problem may arise, of course. There are two consequences: the value of property rates increases and the risks too. The acquisition of skills by paying wages lower than their real economic contribution increases the value of property rights in the equity capital, but even increases risks since business requires continuity of managerial competence supply and rear of skills. Conversely, when corporate ownership and control overlap, principal-agent problems can arise in case of transferability of property rights are transferred over to the company which contributes to lower the value of the firm. In this case the necessity of an agency contract between seller and buyer relates to the competence persistence after the deal is concluded (Williamson and Masten, 1999). Still here, overconfidence evidence may arise for other financial market agents such as analysts (Hilary and Menzly, 2006; Chen and Jiang, 2006) or experts (Griffin and Varey, 1996; Klayman et al., 1999) and relate to the assortment of these specific individuals around forecast-oriented, highly selective professions that call to a great level of risk-taking. Even in these cases, risk aversions get biased. The quest for an entrepreneurial business concept (Covin and Slevin, 1991) is clear, even according to a financial perspective:

- $\quad$ assessing the value of the entrepreneurial competence is utmost complicated since skills and capital are jointed productive factors (drivers) of the entrepreneurial business

- time required by the learning cycle inside the organisation can separate them. The process will be more efficient according to the true behaviour of the entrepreneur

- massive agency problems may arise during the process of skill spread and value emersion, increasing the risk of the investment in the entrepreneurial challenge 
- $\quad$ risk aversions can be biased by misperception and information risk while can be forced to divert from normal levels according to the peculiarities of the entrepreneurial business

- the core measurement question is the identification of the marginal productivity of the inputs (including skills) while time is no more a simple element to compute present value.

As is the case for the so-called 'human capital' (or even for 'business expertise'), in entrepreneurial challenges we are facing a special form of intangible asset with economic profiles that are rooted inside the circuits where knowledge is produced and transferred inside the capital market. This is the competence value: by increasing the portability of entrepreneurial skills via the market (i.e., together with the indistinct capitals) the possibility of observing market prices that incorporate expertise value will increase. The emersion of competence value into market price, however, can be an extraordinary economic incentive to accumulate and cultivate entrepreneurial skills and flow money in entrepreneurial finance transactions. But this process requires time, entrepreneurial commitment and patient investors.

Based on the most affordable evolutions in entrepreneurship studies (e.g., Baumol, 1986) and the previous exposition, we propose an entrepreneurial business concept based on the transformation of competence value into market values using time and the entrepreneur's behaviour to implement efficient learning and organisation processes.

The (competence) value creation is based on skills: no skills means no value. However, such skills do not mean market value: no active behaviour to spread knowledge into the firm prevents market value existence. A further theoretical concept is then required in our model to complete the skills-to-value connection: the value-emersion, i.e., the evolution of untradeable (i.e., very person-connected) potential value into the market price of the business (i.e., very capital-connected). Value emersion firstly requires skills tillage to transform them into competence to be further pullulated into the corporation. Accordingly, a three stages entrepreneurial-cycle can be observed:

1 the entrepreneurial seed, where grafted skills are cultivated to be transformed into competence which requires capital investments (this is the competence-value creation phase)

2 the entrepreneurial pullulating, where higher performances of firm investments emerge, although they are still depending on the entrepreneur agency to the organisation (i.e., the competence value is created but it is not fully sunk back into the firm)

3 the entrepreneurial completing, where competence budding gets complete and the corporation benefits from fully embedded knowledge (competence emerges into market values).

The entrepreneurial cycle cannot be interpreted correctly when adopting the standard concepts of management. Hisrich and Kearney correctly explain: "management is the transformation of inputs into outputs through conceptual, human and technical skills" while "an entrepreneur is future oriented, seeking opportunities and identifying innovations to fill opportunities" [Hisrich and Kearney, (2012), p.5] As John Stuart Mill suggested since 1848, the key difference between management and entrepreneurship is the bearing of risk. In fact, return-to-risk profiles are very specific for each of the three 
stages and, consequently, the entire cycle cannot be fully interpreted through standard financial conceptual frameworks. In corporate finance, the value creation process is typically related to the emersion of a 'per se' goodwill of the assets. On the other hand, in entrepreneurial finance such a process is filtered by (i.e., related to) the actual behaviour of the entrepreneur who "assume the major risks in terms of equity, time and career commitments by providing value for a product of service" [Hisrich and Kearney, (2012), p.11]. Entrepreneurial finance is based on a behavioural risk model that clearly separates the treatment of 'resident risk' from that of 'behavioural risks' (Yazdipour, 2011): indeed, an ante-litteram perspective theory. Still Hisrisch and Kearney help us to better distinguish the two approaches as follows:

\begin{abstract}
"To an economist, an entrepreneur is one who brings resources, labour, vision, materials and other assets into combination that increase product or service value and introduce and implement change, innovation and a new order. To a psychologist, such a person is typically driven by certain forces - the need to attain something, to experiment, to accomplish or perhaps to escape authority." [Hisrich and Kearney, (2012), still on p.11].
\end{abstract}

Comparing the dynamics of productivity that determines the returns and the risks of the entrepreneurial challenge over the entire cycle with that of the standard competitive company might be useful to detect the differences between the two approaches and distinguish between competence-driven and goodwill-driven value creation processes. Figure 1 helps to understand: the red-line depicts productivity of a competitive (i.e., goodwill generating) corporation, while the blue-line reports the case of a competence-driven one; both are compared with the expected return from an indistinct capital, the green-line (i.e., the cost of capital).

Figure 1 The dynamics of observable business productivity (see online version for colours)

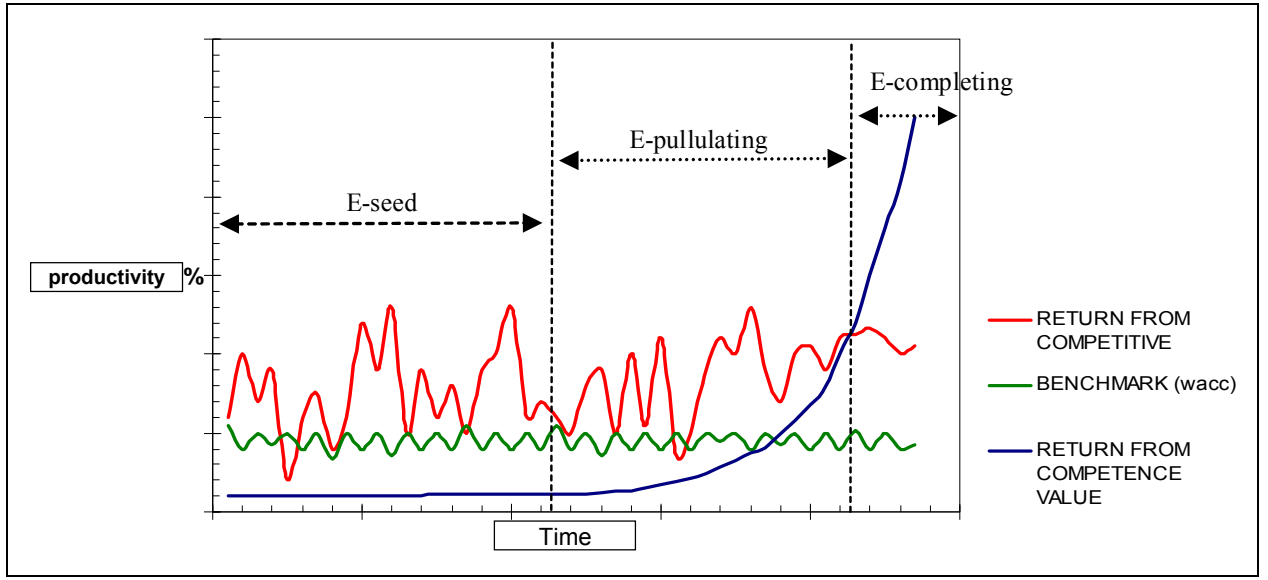

In the e-seed phase, entrepreneurial returns seem lower than the expected ones, while risks are higher than supposed. But this can be a misperception: flows from firms are low because of compensation between good margins and yearly budgets to be spent by the entrepreneur for skills transformation into competence. Such investment cannot be accounted for, at least according to standard accounting principles. It seems to be more likely a sunk cost, decided by the true behaviour of the entrepreneur who is accumulating the competence. This contributes to misperception. Corporate value is (apparently) very 
low because current return gaps are perceived to be persistent, without any possible control over their recovery in the next phases. The typical short-termism that affects the financial system may inflate the misperception. It can be justified by the objective difficulties in detecting the true efficacy of the process of skills tillage that is carried on. This explains why business angels with competences similar to those of the entrepreneur are the key corporate investors for these phase. They contribute to the process more than they do to the financial needs.

In the e-pullulating phase, the competitive advantage due to the accumulated competences emerges through a gross margin increase while sunk costs due to competence administration are reduced. This contributes to reduce (apparently) corporate risk due to the use of unfairly-paid-competences: in fact, a sound entrepreneurial behaviour leave the over profits into the company. In this second phase of the entrepreneurial cycle, corporate value increases along with the increase of financial flows, but a gap between potential (fair) value and market value still exists due to huge percentage of 'behavioural risk' (Yazdipour, 2011) embedded into corporate flows. Still, the higher fair value is more related to the person of the entrepreneur than not to the efficiency of the corporate nexus.

In the e-completing phase, the competitive advantage is fully acquired by the corporate nexus becoming more and more independent from the entrepreneur's behaviour. The corporate performance is strongly higher than the benchmark and gaps between potential and market values are reduced via goodwill values emersion, since cash flows are strongly higher than the most performer competitor. At this stage the entrepreneur may prefer to move into further E-seed phases so that governance related choices can be required. An agency problem emerges: who is entitled to acquire the higher value, i.e., how the value is to be shared between the entrepreneur and the corporate stakeholders? A great agency trouble, very difficult to solve.

Even if return-to-risk profiles in the three stages are very specific, valuation should refer to the three as a whole since the persistency of the entrepreneurial contribution is the common root. The value that gets visible during the last phase was existing even in the seed but was invisible, because of difficulties in detecting (perceiving) the persistency of competence contribution to the corporate performance over the entire cycle. No persistency means no value emersion (Zahra and Covin, 1995): persistency is then the key factor to measure the competence value, because this is the essence of the entrepreneurial art.

Accordingly to the above depicted model, we can understand how easily the competence value can be confused with the value of goodwill, concluding that 'no goodwill means no competence'. But this is due to the misperceptions of the true roots of the return-to-risk paths of the entrepreneurial business: the typical mistake one can observe in the use of Basel-related tools, thus arising an information risk that reduces capital allowances to SMEs. In fact, goodwill is a negotiable value because it assumes that the purchaser is able to fully appropriate the benefits that might derive from investing, i.e., it is already instilled in the organisation through competitiveness. Competence value is instead an un-negotiable value, a starting point which leads to a potential state, because it is not entirely feasible without completing the cycle of knowledge-transfer to the company structure and without the entrepreneurial behaviour. In entrepreneurial business cycles, goodwill is not a 'per-se' asset, but the final evidence of the competence persistency inside the corporate nexus during the entire cycle. The requirement of persistency needs specific entrepreneurial finance tools to support the 
transformation process of the competence value into goodwill. Long term financial tools are required in order to contribute to control the agency profile of the entrepreneurial behaviour and to have a correct perception of the resident risks vs. the behavioural ones. Maybe, structured debt-funding with legal entrepreneurship commitment (covenants) provides good support. Full shareholders performance will get only later, in the third stage. This leads to discuss entrepreneurship form a financial point of view.

\section{The entrepreneurial value in incomplete financial markets contexts}

Although it may seem like a seemingly simple question of semantics, value and price of capital are not synonymous. Adopting an incomplete financial markets approach is exactly the starting point for the entrepreneurial value measurement challenge.

Price is the value as defined by the markets. It is, by its nature, objective, expressing the yardstick that the financial market uses to evaluate the current monetary equivalent of future economic benefits to obtain by the use of capital. The present value is the calculation methodology that allows us to understand the mechanism by which the financial market defines the above equivalence. Time and risk contribute to the determination of an annual rate of equivalence (i.e., the opportunity cost of capital), whose practical use is dependent upon the duration of the time horizon of a specific flow of wealth (discount factor). For the later purposes of this paper, consider the functionality of the time in the present value calculation as being well defined, contributing to a very small source of uncertainty, both in determining the cost of capital (Copeland et al., 1995) and in the calculation of the discount factor. Neo-classical finance solves time uncertainty either by the adoption of instantaneous-time models (such as the standard CAPM) or by the adoption of continuous-time models (such as the Merton's model). Both approaches aim to determine the relationship between risk and time (Merton, 1990) through the identification of a market portfolio (Tobin, 1958) to which all investors refer, regardless of their utility function. In this context, therefore, financial markets and intermediaries become perfect transformers of maturities and risks through their monetary certainty equivalent: the prices of capital. Having solved the maturity and risk puzzle, the market price is 'the value'. The market quality must refer only to frictionless situations, i.e., information, transaction costs, taxes, etc. do not have to impact on price determination. The better the functionality (efficiency) of the market, the greater the information embedded in prices so that they become more reliable.

Why have a value (i.e., a potential market price) other than market price in financial theory? Basically for two reasons:

1 to correct market failures

2 to outline subjective expectations on the set 'economic benefits vs. risks-to-time twins' (Arrow, 1971; Debreu, 1959).

The scholarly attention has usually more focused on the former because un-equilibrated markets are noises. While ignoring the second, we miss sound models to explain what happens in the true world as the (sound) behavioural finance would try to do (Yazdipour, 2011). Moreover, we miss the idea that some forms of capital could be untradeable. This may happen because of the difficulties in detecting the complex mechanisms of flows generation, perhaps even for objective difficulties of calculation (information risk bias). 
In reality, however, the different perception of the true set (time-benefits-risks) strives to articulate a specific time equivalence of the flows of funds based on a subjective set of expectations and risk tolerances both strongly jointed: that is the value of capital. The greater the difference between value and price of capital, the more likely it is the activation of negotiations (Rubinstein, 1975), thus ensuring the survival of the market (Latham, 1985). Consequently, the value-to-price gap is an economic incentive to complete the markets, but do not deny the existence of market equilibrium. Contrarian to normal acknowledge, the relationship between value and price not only indicates the degree of market inefficiency, but also detects the distance between the set of subjective expectations of those who deliver value and the more general one embedded in the market prices. The more this happens, the greater the possibility that uncertainty can be resolved out of the identification of the unique market portfolio. The maturity transformation capability of the financial system is bugged and the markets remain incomplete.

The efficiency of the financial markets is therefore no guarantee of convergence between value and price. It is only a precondition for transactions to make it easier to facilitate the convergence. In order for price and value to match instantly, market efficiency is the condition that facilitates the possible overlap of the time-benefit-risk set relative to the expectations of potential sellers and buyers. However, this condition is necessary (not sufficient) because an additional factor contributes to the gap between value and price: the inability (or failure) of the financial market to set a price for certain capital goods. This is the case when financial markets are defined as incomplete (Allen and Gale, 1994). Their operating mechanisms are not distorted by friction functional, such as transaction costs, which reduce the degree of efficiency. On the contrary, in incomplete financial markets there is a situation in which there is a set of (efficient) prices relating to a fraction only of capital goods, which are the negotiable-assets. This has effects even on the value (not price) of un-negotiable-assets through changes in the cost-effectiveness of the use non-tradable capital through its marginal productivity (Mantovani, 1998). This is particularly true in cases when un-negotiable-capital is bound by ties of joint productivity with the tradable one: entrepreneurial finance is a typical case. Once again, the cost-effectiveness of the use of the mix of negotiable and un-negotiable capital (i.e., their joint productivity) introduces convenience in negotiating the capital that is now non-negotiable within the financial markets.

\subsection{Corporate finance vs. entrepreneurial finance}

A typical example of low-negotiable asset is represented by all those intangibles that deploy their productivity along with an indistinct capital that is more easily financed in the market. If productivity of the indistinct capital is closely related to the intangible assets owned by the company (as in the case of the entrepreneur's know-how of many SMEs), the market price of the capital cannot incorporate any indistinct surplus (i.e., goodwill). In this case, the sale of the indistinct capital can destroy the connections of joint use of this capital with the intangibles and the right of its economic exploitation. The value exists but it struggles to be embedded in the negotiated price of the indistinct capital. In these cases, the ratio of 'specific-to-standard' expected cash flows is a driver more than any other to explain the difference between perceived values and market prices (Massari and Zanetti, 2004). In fact, the former assumes the continuity of the link, while the latter supposes its dissolution. In these cases, the seller of the capital will often have 
the feeling of having 'sold out' the company because the value it receives incorporates productivity that is not replicable by the buyer. At the same time, in the event that the intangibles had inextricably links with the corporate structure, the transfer of contingent rights on capital would also involve the transfer of exploitation rights of the future productivity of intangible assets and the relationship between value and price would accordingly be closer. This tends to complete financial markets because of the negotiation of a bundle that integrates indistinct intangible assets into capital. However, the different perspectives of exploitation of intangible assets from potential buyers in competition with each other could again make it otherwise attractive to buy them. This would lead to the incorporation in the prices of the value of the future exploitation of intangible assets and thus make prices 'off market' for certain buyers and 'extremely favourable' to others. The completion of the market could then increase its efficiency by enabling the negotiability of intangible assets separately from the indistinct capital. Efficiency would be further enhanced by allocating capital through transferability of only one part of the capital with lower transaction costs (because the transaction would be no longer anchored to the afferent indistinct capital), expanding the audience of potential buyers.

The corporate goodwill is a clear case of negotiable intangible asset, while competence value is typically a low/un-negotiable intangible asset. The possibility of misperceptions that lead to confuse each other is very high. The critical issue emerges especially considering the fact that they both directly affect expectations regarding the cash flow, time horizons, perceived risks, degrees of risk aversion and, therefore, risk premia: all the economic components of the gap between price and value, i.e., the market incompleteness. Cash flow projection is more difficult in the case of competence value estimation due to the longer time horizon required and for the functionality of time as value-driver of the entrepreneurial success: estimate bias can increase dramatically along with the information-risk, particularly at corporate level and the specific risk-premium that it embeds into the cost of capital (Mantovani, 2012). The more the financial markets are incomplete, the more the misperception is probable while confusing goodwill and competence value shorten, indeed, the time horizon of the analysis. If you think carefully about standard financial analysis practices in cash flow estimation, they usually adopt formulas based on short-term figures. Short-term competitive condition is supposed to be the ultimate value driver (Chen and Steiner, 2000). This generates even more information bias and misperception.

An accurate return-to-risk analysis, only, could help to identify correctly the nature of values (Fama and MacBeth, 1973). If you think carefully about the features of the contribution of time to the entrepreneurial business model, particularly into the process of joint production of capital and skills (Orser et al., 2007), you can identify specific imprints of the four variables acting as common matrix for the dynamics of competence value and goodwill (i.e., cash, time, payoff-risk and risk aversion/premium). This analysis is useful to avoid the information risk bias (Reuber and Fischer, 1999).

Goodwill is a capital asset whose economic paradigm is based on the input-output logic, similar to many other factors of production. The input of this process is the competitiveness. The output is expressed by returns-to-risk ratio of the invested capital higher than the cost of capital. Similar to the case for any other productive factor, the input destruction through a consumption process is the necessary condition for the production of the output itself (Rullani, 2004). Time is the technical condition that allows the input-output process to happen: this is why we compute lower present values; the 
longer is the time horizon. As per any other commodity, however, it is possible to reconstruct the input providing maintenance or replacement investments which are capable of impacting the process of depreciation (i.e., capital consumption). Unlike physical capital goods in which the technical component contributes significantly to the amortisation of business, in the case of goodwill the opposite may happen. This is because the competition (the input) also significantly depends on the dynamic economic environment surrounding the company. Thus, the drivers of the depreciation of goodwill are consistent with what happens in the normal world of business, this being the essence of the managerial work. The proof lies in the fact that the new accounting standards state that managers are responsible for the goodwill value adjustment on the basis of the impairment test (Bini and Guatri, 2003) or as a result of joint verification of the impacts of the decisions of businesses and environmental dynamics on the value of goodwill. However, while this vision is closer to those adopted into financial markets, it maintains the principle of the consumption of the input for the realisation of output. That is why goodwill is usually considered in financial analysis ratio as a support for funding decisions.

Competence value, on the other hand, is a corporate feature based on a process that uses the initial entrepreneurial knowledge as input (e.g., the ability to perform a particular production activity) to transform it into competence in order to spread it into the corporate nexus. Very differently from the goodwill case, when the process is completed the input is not destroyed, but is cloned during the accumulation process. Consequently, the initial knowledge must follow the release of other knowledge. The time is no longer merely a technical element: it is one of the key inputs. In fact, different productivities of inputs are to be given the necessary time to develop a cross-fertilisation between knowledge input and that which occurs independently in the structure. In the phase in which knowledge is accumulated, there is 'loss of time' as a factor of production, creating a major problem of perception and agency. There is, therefore, no improvement of the immediate performance economic (because you have to wait for the completion of the accumulation process) thus leaving space for phenomena of opportunism that would consume resources that would otherwise be used. In contrast, the more developed the process of accumulation is, the more the complexity of the 'capital + skills' overall productivity will grow rapidly and increase economic performance, without affecting the cognitive capital.

Entrepreneurial finance transaction success may be influenced by the completion grade of the financial market and its affection to the marginal productivity of capital, thereby by altering the forms of cost-effectiveness of the use of the entrepreneurial value. In fact, in incomplete financial markets, potential externalities relate to:

1 the opportunity to get assets with a higher value-to-price ratio and therefore allowing to gain a higher-profit

2 the dissolution of an asset price when its negotiation means to cut the link between its productivity of the one of another untradeable-asset left to the seller.

In other words: case 1 refers to financial investors that may easily bargain undue value from entrepreneurs who require completing the skills spreading cycle; case 2 takes place in share selling by very skilled entrepreneurs before the spreading cycle to complete. In both cases, it is a governance puzzle. The ability to contribute to the completion of the 
market, thereby increasing the overall economic benefit and creating space for a specific economic reward is an incredible challenge to entrepreneurship and entrepreneurial finance professionals. We suggest considering any entrepreneurial finance deal as an attempt to search a financial solution to fund the entrepreneurial business while completing the financial market. This is, indeed, the only way to transform personal skills into corporate competitiveness and let competence value emerge into market price. The financial solution must even prevent any agency conflict inside the corporation, while adapting to the specific investor's risk aversion.

\subsection{Debt and equity capital in entrepreneurial finance}

The primary impact of the opportunity given by market incompleteness is over the use of debt in the capital structure of entrepreneurial businesses. The neo-classical financial theory gives us a model suggesting that financial leverage can be pushed to levels where the marginal positive contribution of the tax shield induced by debt is equal to the negative impacts led by agency costs and bankruptcy (Robichek and Myers, 1965). In this theoretical context, however, the reference data are the book values of the assets as represented in financial statements, which are set equal to market values according to the hypothesis (not always so explicit)of market completeness. But if financial markets are incomplete, (book) values and prices differ a lot, making the application of the classical approach very difficult (Mantovani, 2003). Moreover, the presence of significant agency costs resulting from the frozen conflicts for the appropriation of economic benefits from the use of skills make it even more difficult to apply. In these cases you need to abandon the classical models of finance to accommodate contingent claim approaches to corporate finance, which are based on the more general state-preference concept framework (Arrow, 1971; Debreu, 1959). On this basis, the theoretical distinction between debt and equity capital is fully outdated as it is based on the quantity only of the (indistinct) risk to be covered by the lender. Contingent (and entrepreneurial) finance must instead be based on loan agreements which aim to design suitable shaped return-to-risk opportunities both in terms of quality and quantity. Accordingly, the design of debt contracts helps to solve the agency puzzle in entrepreneurship (i.e., value emersion) and to match the corporate need with the specific investor's risk tolerance in terms of: duration, clauses, covenants to specific types of performance variables, formulas to guarantee non-property rights, etc.

From a legal point of view, this is still debt capital (Diamond, 1991) but from an economic point of view it is not. It is primarily structured-capital since its value does not depends only on the assets price but it is even contingent to the ability to adapt its flows to the productive conditions of the business. This is the only way to access point-to-point financial transactions which is otherwise not achievable. It is then a settled-capital not only because it is provided through a financial intermediation, but since it requires the intelligence of a third party (i.e., not necessarily a bank) in the interpretation of the main drivers of the production cycle in order to design or compose the tools that best suit to the needs to be covered. Finally, it is a patient capital because:

1 is based on a variable time horizon of the investment cycles

2 requires an investor's risk aversion consistent with a business risk that cannot always be replicated in the market, neither being part of the systematic or diversifiable risk. 
In the first case, it would otherwise be replicated and the market would be complete. In the second, you must abdicate the signing of contracts instead of putting together a diversified portfolio.

We will refer to this meta-debt funding as the 'capital-quota' (Mantovani, 1998) of the entrepreneurial finance deal. It is a monetary capital that becomes available to the entrepreneurial business in a contingent financing transaction (Nevitt, 1988). Remuneration is mainly based on co-participation in the results of a specific undertaken action. The value of the capital-quota depends on the contribution that the funding brings in the accumulation of asset values or on the contribution it makes to the productivity of the productive factors funded through it. But in entrepreneurial financing transactions, even an 'expertise-quota' is required to allow coverage of financial requirements mainly to support cash outflows that transform skills into competitiveness, particularly in the first two steps of the entrepreneurial cycle. This funding will be still contingent, but to the competence value itself and its farming and emersion into the goodwill at maturity of the entrepreneurial cycle.

The use of debt-styled contracts may help to have a legal framework that is more friendly for the resolution of agency problems involved in competence value emersion. In fact, it is more likely that the capital-quota of the transaction will tend to assume many of the characteristics of debt but it will also embed some of the equity capital due to the expertise-quota. Indeed, the debt-financing framework makes it possible to incentivise the contribution of entrepreneurial skills to corporate performance and it leaves to the entrepreneur the opportunity to acquire large portions of any excess-earnings until the expertise-quota of the financing fully completes the transformation of competence value into goodwill (i.e., it completes the market through the emersion of negotiable value). On the opposite side, the economic analogies with equity capital reduce the agency conflicts related to the reduction of the corporate solvency which could arise from the destruction of productivity conjunction of the productive factors. This similarity with the equity (venture) capital is granted with a fair return at the very end of the competence emersion cycle by the liquidation of an high share of emerged-value-of-the-skills (goodwill). Thus, the investor's expectations of performance will be satisfied along with the asymmetry of the distribution of risks between the lender and the entrepreneur in the stages of skills farming. The provisions charged over the funded entrepreneur, such as resale share-capital constraints or other covenants (Unicredit Banca, 2004), will be the technical gateway to solve the legal puzzle.

\section{Measuring competence value through the T-ratio}

To carry on these financial deals in order to take advantage of both the entrepreneurial opportunities and the financial markets incompleteness, sound methodological tools are required to estimate the potential value of skills during the entire entrepreneurial cycle and to bypass the myopia that affects financial markets and intermediation. It is well known that relative changes of competitive return to cost of capital dynamics permits to compute the CAPM-beta, thus to price a fair risk premium. But this approach is not practically applicable to competence driven business, since returns emersion requires time to complete the cycles. Only standard competitive business can be valued according to a financial pairing process. 
The market value of a typical competitive corporation can be computed as the present value of expected (i.e., volatile) cash returns. Supposing a steady state firm (this only to keep easier the exposition of the model), maths of price computation are reported in equation (1).

$$
P=\frac{E(C F)}{k}
$$

Being: $P$, the market-value/price of the company; $E(C F)$ the expected level of cash flows; ' $k$ ' the cost of capital

If the corporation is competitive, its book returns ' $r$ ' are expected to be above the ' $k$ ' level

$$
P=\frac{E(C F)}{k}=B V \frac{r}{k}
$$

Being furthermore: $B V$, the book value of assets; ' $r$ ' the corporate rate of return

Their price-to-book value ratio reflects the $r$-to- $k$ ratio for any given level of systematic risk.

$$
\frac{P}{B V}=\frac{E(C F)}{B V k}=\frac{B V r}{B V k}=\frac{r}{k}
$$

Notice that ' $r$ ' is a book return rate.

Given a certain level of risk, the market value will be higher than book value (i.e., goodwill exists) if the corporate rate of return is higher than the cost of capital (i.e., profitability is deployed). The market value of goodwill is exposed in equation (4) still considering a steady business

$$
G=P-B V=B V\left[\left(\frac{r}{k}\right)-1\right]=B V \frac{r-k}{k}
$$

Being furthermore: $G$, the market value of goodwill.

Let us consider now the case of an entrepreneurial venture which has a similar competitive initiative of the previous company in addition to grafted skills. In the e-seed and e-pullulating phases, lower expected cash flows are generated until grafted competence is fully cultivated into the firm. Consequently, the lower value can be estimated according to equation [1bis]:

$$
W_{1}=\frac{[E(C F)-E(X)]}{k}=B V \frac{r-x}{k}
$$

Being $W$ the estimated (i.e., fair but not market) value of the entrepreneurial business; $E(X)$ the expected yearly investment required for competence pullulating; ' $x$ ' is the ratio of $E(X)$ to the book value of the company

Should the e-seed perpetuate, the price-to-book value ratio would reflect the $(r-x)$ to- $k$ ratio.

$$
\frac{P}{B V} \rightarrow \frac{W_{1}}{B V}=\frac{[E(C F)-E(X)]}{B V k}=\frac{r-x}{k}
$$


If ' $x$ ' is positive, $W_{1} / B V$ will be lower than fair $P / B V \ldots$ apparently! In fact, if successful, the competence spreading into the corporation would generate higher return-to-risk after ' $t$ ' years. In other words, the e-pullulating stage would begin and tends to complete the value.

The missing value at time zero can be described as depicted in equation (1-ter):

$$
W_{2}=\frac{\frac{p}{1+k} E(X)+E(C)}{k}
$$

Being ' $p$ ' the probability of entrepreneurial success; $E(C)$ the over-cash flow due to competences now put at work; ' $t$ ' the required time-spreading of competences (e-pullulating phase duration).

The missing price-to-book value at time zero will be:

$$
\frac{W_{2}}{B V}=\frac{\left[\frac{p(x+c)}{(1+k)^{t}}\right]}{k}
$$

Being: ' $p$ ' the probability of entrepreneurial success; ' $c$ ' the excess return generated by competences at work $(=E(C) / B V)$; ' $t$ ' the required time-spreading of competences (e-pullulating phase duration).

The gap between the values of the competitive-only company $(P)$ and the complete value of the skilled company $\left(W_{1}+W_{2}\right)$ depends on the relationships between ' $c$ ', ' $x$ ', ' $p$ ', ' $k$ ' and ' $t$ ', the entire set of determinants of $W_{2} / B V$. Equation (5) shows the conditions to have $P=W_{1}+W_{2}$

$$
c \frac{p}{(1+k)^{t}}=x\left[1-\frac{p}{(1+k)^{t}}\right]
$$

If the entrepreneurial project is successful (e-completing stage occurs) $W_{2}$ is transformed into market value, thus regenerating the missing value (including goodwill). We fix $W_{2}$ as the competence value estimation. The un-emerged value due to e-cycles to complete.

One can now catch better the difference between goodwill and competence value discussed above by comparing equation (1) with (1bis). Generally speaking, $P \geq W_{1}$. In fact, according to equation [4] we can conclude that

$$
P-B V=G \geq W_{1}-B V
$$

and the lemma that

$$
G \neq W_{2}
$$

Competence value is different from goodwill value indeed! The math conclusion clearly represents the very different economic concepts (i.e., contents and drivers) of $G$ and $W_{2}$. More important, one can argue how dramatically different the functionality of time in the competence value case is from the goodwill one discussed above: in the case of goodwill, time is an instrument for value measurement only (i.e., it is used to calculate a present value); in the case of competence value, time is even an underpin of the business success, 
filtered by the probability ' $p$ ' (i.e., it is a must to complete the capital accumulation process).

Based on previous equations, the analogies between the theory of incomplete financial markets and that of the entrepreneurial business mechanics are clearer. $W_{2}$ is the present hidden value that could emerge from the entrepreneurial behaviour (i.e., the expertise-quota of funding), $P_{0}$ (or $W_{1}$, according to the level of market efficiency) is the current market value that could encourage investors to enter entrepreneurial finance ventures (i.e., capital-quota of funding). At time ' $t$ ' (i.e., when competence cultivation cycle is completed) $P_{t}$ could be particularly high if the company truly enters the e-completing phase.

Accordingly, an entrepreneurial finance life-cycle can be depicted as such:

- In the EF-seed phase, the negotiable-capital (i.e., the capital-quota of financing supporting corporate investments) is required to subordinate returns, diverting them to investment into grafted skills transformation into competence value. Contingent rights over competence value (i.e., expertise-quota) are required to invest in the reduced-current-returns-business and control agency troubles arising from the entrepreneur.

- In the EF-pullulating phase, the negotiable-capital is required to subordinate maturity to actual competence deployment into corporate organisation. After the e-seed phase, returns can be paid out but are now contingent to the entrepreneur persistence inside the firm. In case of her/his abandonment, the competence value would dissolve and generate severe capital loss to investors. That is why entrepreneurs are bind to specific covenants and other non-capital constraints.

- In EF-completing phase, the negotiable-capital is required to subordinate tradability to market opportunities mainly due to market efficiency and return-to-risk is related to specific levels of risk aversion.

Risk aversions (of both investors and entrepreneurs) are indeed the key financial factor in all three phases since they determine the true behaviour of the two economic agents (Ross, 2002; Gardenal, 2010). The unique role of time in competence spreading would already be sufficient itself to require specific levels of risk aversion in funding entrepreneurial activities. But in this case the risk-to-time relation is complicated by a state-contingent evolution of the life cycle (synthesised as ' $p$ ' in the model) that is dramatically linked to the actual behaviour of the entrepreneur itself. Consequently, the risk aversion level is affected by the quest of contendability of the economic value of competences, which is an agency problem, indeed. A state-preference approach can help us in value discovery of competence value which avoids complexities arising from risk aversion treatment. Just this intuition helps us to model persistence, the key factor of the entrepreneurial business. In fact, according to the above explained business model of entrepreneurship, we can track its life-cycle in a real-option approach (Schwartz and Trigeorgis, 2004) as follows. The entrepreneurial success can be interpreted as a real call option over $W_{2}$ which has an expected maturity at time ' $t$ ' (fixed only ex-post, according to the actual duration of the e-pullulating phase). Being a European-style option (i.e., to be exercised at maturity only), such an option highlights these economics: 
$1 \quad\left(P_{0}-W_{1}\right)$ is the option premium to call $W_{2}$. Payment is done during the EF-seed phase

$2\left(W_{1}+W_{2}\right)-P_{0}$ is the intrinsic value of the option when it enters in-the-money paying cash returns due to competences but still cannot be exercised being in the EF-pullulating phase

$3\left(P_{t}-P_{0}\right)$ is the true payoff of the option during the EF-completing phase.

The model for pricing of such an option can be very complex, maybe useless in actual SME funding practices. A more exploitable method has to be found. Considering that such a model refers to un-negotiable capital (i.e., supporting decisions, but not market value of wealth), we can accept to use a proxy-valuation approach to estimate such a real option value.

A huge help may come from Lintner's approach to asset pricing (Lintner, 1965). Such a model is based on a bottom-up approach, i.e., it is not required to collect data from complete financial markets to discover investment values. Oversimplifying the original model, Linter suggests estimating values by discounting the certainty equivalent on a risk-free rate. Avoiding the risk-premium estimation in discounting rate, the model does not require a market portfolio benchmarking. Results from Linter's model are consistent with Tobin's two-fund-separation theorem for the risk aversion impact on the equilibrium of financial markets. Not only Lintner's model does allow achieving the same results as other models but also allows the development of applicable methodologies even in incomplete markets.

In his seminal work, Lintner demonstrates that:

1 you can determine the value by discounting certainty equivalent of cash flows $(C E)$ using the risk free rate $\left(R_{f}\right)$

2 the result is exactly the fair price you can find with market models. So, we can spread out the following equation ${ }^{1}$ :

$$
\frac{E(C F)}{k}=P=\frac{C E}{R_{f}}
$$

Being, furthermore: $\mathrm{CE}$, the certainty equivalent of $E(C F),[C E<E(C F)]$; ' $R_{f}$ ' the risk-free rate, $\left[R_{f}<k\right]$.

The consequence is that:

$$
\frac{C E}{E(C F)}=\frac{R_{f}}{k}
$$

or

$$
C E=E(C F) \frac{R_{f}}{k}
$$

All previous computation can be relativised to book-value and compared with equation (2) so that the following equation can be written:

$$
\frac{r}{k}=\frac{P}{B V}=\frac{r^{*}}{R_{f}}
$$


Furthermore: $r^{*}$ the book return rate based on $C E(=C E / B V)$; ' $R_{f}$ ' the risk-free rate.

The inner difference between the Lintner's approach with those referring to complete markets (such as the CAPM) is at methodological level. This is a bottom-up approach that does not require to have already a market equilibrium to fix prices (i.e., no loops link the price discovery and the required market equilibrium, as the CAPM does obliging one to detect peer-groups in corporate valuation). The complexity of the estimation of risk-premium is substituted by that of the CE estimation. Our suggestion is that in incomplete markets Linter's approach can reduce bias and the information risk, finally the perspective gap. This is because the bottom-up approach will concentrate the analysis at corporate level and avoid mistakes arising from extraction of market related indicators in incomplete contexts.

We can usefully merge Lintner's approach with the previous entrepreneurial business concept. According to Lintner's approach, we know that both price-P and value-W are to be based on the same certainty equivalent; the further condition for market completion $P=W_{1}+W_{2}-$ let the following equation be true:

$$
C E=\left\{[E(C F)-E(X)]+\frac{p}{(1+k)^{2}}[E(X)+E(C)]\right\} \frac{R_{f}}{k}
$$

It is particularly important to point out that previous equation uses book data only to estimate values (i.e., it uses the same data normally adopted in widely used financial statement analysis). The previous equation can be written in terms relating to $B V$ as follows:

$$
\frac{W_{1}+W_{2}}{B V}=\frac{(r-x)+\left[\frac{p}{(1+k)}(x+c)\right]}{k}=\frac{r^{*}}{R_{f}}
$$

At industry level, the quantitative level of $r^{*}$ (i.e., the book-CE threshold level) can be estimated according to a shortfall approach (Leibowitz, 1995). The joint distribution of ' $r$ ', ' $x$ ' and ' $c$ ' is then used to determine $r *$, given a confidence level to be estimated according to the two basics of entrepreneurial business success: ' $p$ ' and ' $t$ '. Thus, an estimation of competence value can be done through a bottom-up (i.e., corporate/industry level) estimation of $r^{*}$ as follows:

$$
r^{*}=i-S H F+N(\phi) \sigma_{i}
$$

Being: $i-S H F$ the shortfall level of return at $\phi$ confidence level, $\sigma_{i}$ the standard deviation of book return rate for $i^{\text {th }}$ investment, $N(\phi)$ is the standardised normal distribution figure, given a fixed confidence level.

According to Lintner's approach, however, value estimations through CE must reflect the average risk aversion of investors, which means that market shortfall computation should generate the same numeric result. The numeric result of equation (9) should be validated by comparing it to market conditions. A market level or ' $r$ ' can be estimated using the distribution of market returns (i.e., ' $k$ ') according to the market evidence of risk aversion. Thus, a top-down confirmation of the competence value estimation can be made through market data as follows

$$
k^{*}=m-S H F+N(\phi) \sigma_{m}
$$


Being: $m-S H F$ the shortfall at $\phi$ confidence level, $\sigma_{i}$ the standard deviation of returns for the entire market, $N(\phi)$ is the standardised normal distribution figure, given the same fixed confidence level.

In equilibrium $r^{*}=k^{*}$. In fact, according to the Lintner's hypothesis, equation (10) should be true:

$$
m-S H F=i-S H F \quad \forall i ; \forall \phi
$$

Once you have a confirmed estimation of $r^{*}$, you can validate $W_{2}$ computation and verify the actual capability of the industry/company to override the $k^{*}$-threshold in the time-horizon according to the confidence level, thus applying in practice equation (8bis) as indicator of persistency. Please notice that the use of confidence estimation for the shortfall level is consistent with the persistency required for competence value existence but also with the value-at-risk approach adopted inside Basel-related risk measurement systems. Fixing the shortfall confidence means to know the average risk aversion of the market. In the case of Basel risk measurements, the shortfall level is $1 \%$, which means that they know the average risk aversion inside the markets... and that such a risk aversion will never change! According to Linter's approach, instead, the risk aversion is not a determinant driver of the model since the resulting price is the same as the one of a two-fund separation theorem depicted by Tobin (1958). The estimation of a specific risk aversion is then useful to detect the policies of a specific investor or entrepreneur, but not the equilibrium as a whole.

Supposing the book value overlaps the 'reconstruction level', we can use the price-to-book value ratio as a proxy of the Tobin's Q-ratio at corporate level. In incomplete markets, Q-ratio misses $W_{2}$ because it does not consider the value-to-price gap endogenous to the incompleteness. A parallel ratio between $W_{2}$ and the book-value can be estimated subtracting the Q-ratio from a similar indicator estimated on the basis of the Lintner's approach as we propose to amend. In honour of the entrepreneurial spirit of the person giving the name to the foundation that supports this research programme, we decided to call it Intato's T-ratio. Accordingly, Q-ratio and T-ratio computations can be theoretically done by using the following formulas:

$$
\begin{aligned}
& Q=\frac{W_{1}}{B V}=\frac{r-x}{k}=\frac{r_{i}}{k} \\
& T=\frac{W_{2}}{B V}=\frac{\frac{p}{(1+k)^{t}}(x+c)}{k} \frac{r^{*}}{k^{*}}
\end{aligned}
$$

According to equation (8bis), $Q+T=r^{*} / R_{f}$, than $T$ estimation can be confirmed through equation (13).

$$
T^{\wedge}=\frac{r^{*}}{R_{f}}-\frac{r_{i}}{k}
$$

The estimation of $T$ exposed in equation (12) can be done through $T^{\wedge}$ in equation (13), which is the core of the 'Teofilo Intato method' for competence value measurement. 


\section{An empirical example of T-ratio computation}

In this section, we illustrate in practice the fundamentals that underlie the estimation of T-ratio to proxy the competence value. Results will be compared with those arising from a more standard analysis searching for Q-ratio. Both estimations are based on the above steady state approach, suffering a potential time-bias. As explained above, the application and computation of the Intato's method is being developed at industry level ${ }^{2}$ as it emerges from a first application in a sample of companies based in the Treviso's District (here further: TV), the very competitive manufacturing area surrounding Venice in the North-Eastern Italy.

Before describing in detail the selected sample, it is appropriate to emphasise that the collection and selection of data, as well as part of the analysis and calculations were made using the AIDA database, published by Bureau Van Dijk Electronic Publishing, which can be accessed according to an agreement between the Corporation and $\mathrm{Ca}$ ' Foscari University. This database contains accounting information of the Italian companies that make publish their financial reports. The Italian Lawmakes mandatory this disclosure for legal entities bearing limited liabilities over their owners/shareholders. According to the proposed competence value emersion theory, the choice of legal entities to be included in our analysis was based on logic of continuity. In fact, in ex-post analysis we do require the selected companies to have going concern to detect the persistency ${ }^{3}$. That is why our selection includes only those companies that produce accessible financial reports from 2005 to 2009 continuously.

The resulting sample consists of 3,046 companies inside the TV-area, is depicted in Table 1. It includes both firms forced by the Italian law to prepare detailed financial reports (i.e., $26.94 \%$ of the sample) and companies with the opportunity to draw financial statements in the so called 'abbreviated form' (73.06\% of the sample). Both kinds of reports include enough data to validate the competence value in an ex-post approach.

Table 1 Sample composition by industry

\begin{tabular}{lccc}
\hline $\begin{array}{l}\text { Industry (translation of the original } \\
\text { Italian name) }\end{array}$ & ATECO code & SIC code & \# of corporations \\
\hline $\begin{array}{l}\text { Agriculture and hunting services, } \\
\text { forestry }\end{array}$ & $01 ; 02$ & 0 & 63 \\
$\begin{array}{l}\text { Food and drink } \\
\text { Manufacture of textiles }\end{array}$ & $10 ; 11$ & 20 & 115 \\
$\begin{array}{l}\text { Manufacture of clothing, dyeing, } \\
\text { tanning fur }\end{array}$ & $14 ; 14.3$ & 22 & 61 \\
$\begin{array}{l}\text { Manufacture of leather goods made } \\
\text { of wood, cork, straw }\end{array}$ & 15 & 23 & 49 \\
$\begin{array}{l}\text { Manufacture of wood, cork, straw } \\
\text { Manufacture of paper and paper } \\
\text { products }\end{array}$ & 16 & 31 & 53 \\
$\begin{array}{l}\text { Publishing, printing and } \\
\text { reproduction of recorded media }\end{array}$ & $18 ; 58.1$ & 24 & 104 \\
$\begin{array}{l}\text { Manufacture of chemicals and } \\
\text { artificial synthetic fibres and }\end{array}$ & $20 ; 21$ & 26 & 35 \\
\hline
\end{tabular}

Source: Our processing over AIDA database contents 
Table 1 Sample composition by industry (continued)

\begin{tabular}{|c|c|c|c|}
\hline $\begin{array}{l}\text { Industry (translation of the original } \\
\text { Italian name) }\end{array}$ & ATECO code & SIC code & \# of corporations \\
\hline $\begin{array}{l}\text { Manufacture of rubber and plastic } \\
\text { products }\end{array}$ & 22 & 30 & 96 \\
\hline $\begin{array}{l}\text { Manufacture of other non-metallic } \\
\text { mineral processing }\end{array}$ & 23 & 33.5 & 79 \\
\hline $\begin{array}{l}\text { Metallurgy - manufacture and } \\
\text { processing of metal products except } \\
\text { machinery and equipment }\end{array}$ & $24 ; 25$ & 34 & 314 \\
\hline $\begin{array}{l}\text { Manufacture of computers and } \\
\text { electronic and optical products, } \\
\text { electrical appliances, etc. }\end{array}$ & 26 & $35.7 ; 36.7$ & 24 \\
\hline $\begin{array}{l}\text { Manufacture of electrical and } \\
\text { non-electric domestic appliances }\end{array}$ & 27 except 27.5 & $\begin{array}{l}36.1 ; 36.2 ; 36.4 \\
\quad 36.5 ; 36.6\end{array}$ & 62 \\
\hline $\begin{array}{l}\text { Manufacture of machinery and } \\
\text { equipment nec }\end{array}$ & $28 ; 27.5 ; 33.12$ & $35 / 35.7$ & 192 \\
\hline $\begin{array}{l}\text { Manufacture of motor vehicles, } \\
\text { trailers and semitrailers }\end{array}$ & $29 ; 30$ & 37 & 29 \\
\hline $\begin{array}{l}\text { Manufacture of other transport } \\
\text { equipment }\end{array}$ & 31 & 25 & 237 \\
\hline Manufacture of furniture & 32 & 39 & 38 \\
\hline Other manufacturing & $41 ; 42 ; 43$ & $15 ; 16 ; 17$ & 310 \\
\hline Building societies & 45 & 55 & 94 \\
\hline $\begin{array}{l}\text { Trade, maintenance and repair of } \\
\text { motor vehicles and motorcycles }\end{array}$ & 46 & $50 ; 51$ & 483 \\
\hline $\begin{array}{l}\text { Commerce wholesale and } \\
\text { commission trade, motor vehicles } \\
\text { and motorcycles }\end{array}$ & 47 & $\begin{array}{l}53 ; 54 ; 56 ; 57 \\
58 ; 59\end{array}$ & 150 \\
\hline $\begin{array}{l}\text { Retail (excluding motor vehicles } \\
\text { and motorcycles), repair of } \\
\text { personal and household goods land } \\
\text { transportation, pipeline transport, } \\
\text { storage and auxiliary transport } \\
\text { activities }\end{array}$ & $49 ; 52$ & $40 ; 42 ; 47$ & 80 \\
\hline Hotels and restaurants activities & $55 ; 56$ & 70 & 27 \\
\hline Computer and related activities & $62 ; 63 ; 95.11$ & 73.7 & 65 \\
\hline Real estate & 68 & 65 & 115 \\
\hline Professional services & $69 ; 70 ; 71 ; 73 ; 74$ & 87 & 76 \\
\hline Recreational cultural and sports & $\begin{array}{c}90 ; 91 ; 92 ; 93 ; \\
59.1\end{array}$ & $79 ; 83$ & 28 \\
\hline Treviso's District as a total & & & 3,046 \\
\hline
\end{tabular}

Source: Our processing over AIDA database contents 
Data exposed in Table 1 depicts the industry distribution of the firms according to both the Italian standard classification (ATECO) and the SIC code. The number of companies included in ATECO groups is enough to compute affordable descriptive statistics of companies performance for any industry included in the TV-area.

The basic statistics required as input to adopt the method are reported in Table 2.

Table 2 Beta, cost of capital (k), operating returns (ROI) and risks (std. deviation of ROI)

\begin{tabular}{|c|c|c|c|c|c|}
\hline $\begin{array}{l}\text { Industry (translation of the original } \\
\text { Italian name) }\end{array}$ & Beta & $\begin{array}{l}\text { Cost of } \\
\text { capital }\end{array}$ & $\begin{array}{l}\text { Average } \\
\text { ROI }\end{array}$ & $\begin{array}{c}\text { Median } \\
\text { ROI }\end{array}$ & $\begin{array}{c}\text { Standard } \\
\text { deviation } \\
\text { of } R O I\end{array}$ \\
\hline $\begin{array}{l}\text { Agriculture and hunting services, } \\
\text { forestry }\end{array}$ & 0.65 & $7.72 \%$ & $3.38 \%$ & $2.56 \%$ & $9.81 \%$ \\
\hline Food and drink & 0.50 & $6.37 \%$ & $7.91 \%$ & $7.23 \%$ & $9.13 \%$ \\
\hline Manufacture of textiles & 1.60 & $16.27 \%$ & $6.72 \%$ & $6.19 \%$ & $13.62 \%$ \\
\hline $\begin{array}{l}\text { Manufacture of clothing, dyeing, } \\
\text { tanning fur }\end{array}$ & 1.33 & $13.84 \%$ & $11.91 \%$ & $9.60 \%$ & $16.70 \%$ \\
\hline $\begin{array}{l}\text { Manufacture of leather goods made } \\
\text { of wood, cork, straw }\end{array}$ & 1.56 & $15.91 \%$ & $8.87 \%$ & $7.97 \%$ & $11.78 \%$ \\
\hline Manufacture of wood, cork, straw & 1.17 & $12.40 \%$ & $6.63 \%$ & $6.52 \%$ & $10.39 \%$ \\
\hline $\begin{array}{l}\text { Manufacture of paper and paper } \\
\text { products }\end{array}$ & 1.02 & $11.05 \%$ & $6.70 \%$ & $6.86 \%$ & $7.84 \%$ \\
\hline $\begin{array}{l}\text { Publishing, printing and } \\
\text { reproduction of recorded media }\end{array}$ & 1.01 & $10.96 \%$ & $10.00 \%$ & $9.39 \%$ & $10.75 \%$ \\
\hline $\begin{array}{l}\text { Manufacture of chemicals and } \\
\text { artificial synthetic fibres and }\end{array}$ & 0.57 & $7.00 \%$ & $10.97 \%$ & $9.30 \%$ & $11.20 \%$ \\
\hline $\begin{array}{l}\text { Manufacture of rubber and plastic } \\
\text { products }\end{array}$ & 0.97 & $10.60 \%$ & $8.67 \%$ & $7.49 \%$ & $11.57 \%$ \\
\hline $\begin{array}{l}\text { Manufacture of other non-metallic } \\
\text { mineral processing }\end{array}$ & 1.28 & $13.39 \%$ & $6.86 \%$ & $5.86 \%$ & $9.66 \%$ \\
\hline $\begin{array}{l}\text { Metallurgy - manufacture and } \\
\text { processing of metal products except } \\
\text { machinery and equipment }\end{array}$ & 0.96 & $10.51 \%$ & $10.28 \%$ & $9.13 \%$ & $10.93 \%$ \\
\hline $\begin{array}{l}\text { Manufacture of computers and } \\
\text { electronic and optical products, } \\
\text { electrical appliances, etc. }\end{array}$ & 1.31 & $13.66 \%$ & $9.37 \%$ & $9.08 \%$ & $13.21 \%$ \\
\hline $\begin{array}{l}\text { Manufacture of electrical and } \\
\text { non-electric domestic appliances }\end{array}$ & 0.89 & $9.88 \%$ & $8.40 \%$ & $8.55 \%$ & $16.80 \%$ \\
\hline $\begin{array}{l}\text { Manufacture of machinery and } \\
\text { equipment nec }\end{array}$ & 1.26 & $13.21 \%$ & $9.43 \%$ & $8.08 \%$ & $11.71 \%$ \\
\hline $\begin{array}{l}\text { Manufacture of motor vehicles, } \\
\text { trailers and semitrailers }\end{array}$ & 0.77 & $8.80 \%$ & $8.31 \%$ & $7.23 \%$ & $9.42 \%$ \\
\hline $\begin{array}{l}\text { Manufacture of other transport } \\
\text { equipment }\end{array}$ & 1.24 & $13.03 \%$ & $5.25 \%$ & $5.64 \%$ & $11.98 \%$ \\
\hline Manufacture of furniture & 1.11 & $11.86 \%$ & $9.33 \%$ & $8.26 \%$ & $11.04 \%$ \\
\hline Other manufacturing & 0.76 & $8.71 \%$ & $8.94 \%$ & $7.25 \%$ & $9.29 \%$ \\
\hline
\end{tabular}

Source: Our processing over AIDA, Ibbotson and Teofilo Intato Foundation database 
Table 2 Beta, cost of capital (k), operating returns (ROI) and risks (std. deviation of ROI) (continued)

\begin{tabular}{|c|c|c|c|c|c|}
\hline $\begin{array}{l}\text { Industry (translation of the original } \\
\text { Italian name) }\end{array}$ & Beta & $\begin{array}{l}\text { Cost of } \\
\text { capital }\end{array}$ & $\begin{array}{l}\text { Average } \\
\text { ROI }\end{array}$ & $\begin{array}{l}\text { Median } \\
\text { ROI }\end{array}$ & $\begin{array}{c}\text { Standard } \\
\text { deviation } \\
\text { of } R O I\end{array}$ \\
\hline Building societies & 0.59 & $7.18 \%$ & $7.13 \%$ & $6.61 \%$ & $10.42 \%$ \\
\hline $\begin{array}{l}\text { Trade, maintenance and repair of } \\
\text { motor vehicles and motorcycles }\end{array}$ & 0.81 & $9.16 \%$ & $9.43 \%$ & $7.63 \%$ & $11.78 \%$ \\
\hline $\begin{array}{l}\text { Commerce wholesale and } \\
\text { commission trade, motor vehicles } \\
\text { and motorcycles }\end{array}$ & 0.72 & $8.35 \%$ & $7.63 \%$ & $6.84 \%$ & $13.05 \%$ \\
\hline $\begin{array}{l}\text { Retail (excluding motor vehicles } \\
\text { and motorcycles), repair of } \\
\text { personal and household goods land } \\
\text { transportation, pipeline transport, } \\
\text { storage and auxiliary transport } \\
\text { activities }\end{array}$ & 0.92 & $10.15 \%$ & $6.40 \%$ & $6.70 \%$ & $11.58 \%$ \\
\hline Hotels and restaurants activities & 1.62 & $16.45 \%$ & $4.40 \%$ & $3.11 \%$ & $19.90 \%$ \\
\hline Computer and related activities & 0.96 & $10.51 \%$ & $16.45 \%$ & $12.53 \%$ & $18.59 \%$ \\
\hline Real estate & 0.74 & $8.53 \%$ & $5.37 \%$ & $3.99 \%$ & $9.49 \%$ \\
\hline Professional services & 0.92 & $10.15 \%$ & $12.62 \%$ & $8.81 \%$ & $18.57 \%$ \\
\hline \multirow[t]{2}{*}{ Recreational cultural and sports } & 1.10 & $11.77 \%$ & $4.00 \%$ & $5.36 \%$ & $18.04 \%$ \\
\hline & 1.00 & $10.87 \%$ & $8.45 \%$ & $7.18 \%$ & 12.16 \\
\hline
\end{tabular}

Source: Our processing over AIDA, Ibbotson and Teofilo Intato Foundation database

For each industry, the cost of capital has been computed as the book-return threshold based on standard CAPM approach. Computations are based on industry betas extracted from Ibbostson the Cost of Capital Database. Raw data were suitably adjusted to their applicability to the Italian context according to the differential systematic risk between the US and Italian markets.

Moreover, mean and median values of the return on investment (ROI) along with the associated standard deviation are reported. The gap between the mean and median can be an interesting proxy of the existence of companies called 'best performers' that should include those companies which are both competitive (i.e., goodwill based) and expertise-skilled (i.e., competence value backed). These most virtuous businesses are attracting our higher interest to make subsequent investigations, assuming they are to be found to be the most competent ones.

Based on the above illustrated algorithms the T-ratio can be computed for the entire $\mathrm{TV}$-area. We move from standard estimation of the cost of capital of our entire sample. This allows us to have the market shortfall data as in equation (9bis) that coincides with the district one for equation (10).

Our basic hypothesis is that the average systematic risk of the TV-district equals the Italian one so that the TV's beta equals 1.00. The equity risk premium was considered at $9 \%$, higher than the long-term-average Italian level (5.5-6.0\%, according to the surveys by Fernandez et al., 2011). This choice is consequence of the GDP fluctuations, as prescript in Mehra-Prescott's model (Mehra and Prescott, 1985) and of the illiquidity risk for unlisted companies. 
The cost of capital $(k)$ of TV-companies is fixed at $10.87 \%$

$$
k=1.87 \%+(9.00 \%) 1
$$

Being: $1.87 \%$ is the risk-free rate (benchmark Italian treasury bond, BTP) at the time of computation (February 2011)

Long term estimation of the Italian stock market indicates $18 \%$ as the standard deviation of price return on a yearly base. We fixed a confidence level at $10 \%$ which means risk tolerance higher than the one underlying value-at-risk Basel standards (confidence level at $1 \%$ ), but it is consistent with average relative risk aversion (4.00-6.00 according to Bodie et al., 2014) and the correction required for illiquid Italian SMEs. In any event, you must remember that this choice should not have an impact over average results affordability according to Lintner's approach (i.e., the single level of risk aversion is relevant for the specific investor's investment policy). We can compute the shortfall level for the equity risk premium at $10 \%$ confidence as to determine a market maximum tolerated loss, $m-S H F$ as in equation (9bis):

$$
m-S H F=1.87 \%+9.00 \%-1.282 \times 18.00 \%) \times 1=-12.21 \%
$$

According to figures in Table 2, the average operating book return for TV-companies is $8.45 \%$, while its standard deviation of the distribution is $12.16 \%$ (see last line in the table). A correction of the standard deviation has to be made according to the skewness of the distribution, mainly due to different expected growth ratio of the corporation. The corrected figure is $20.66 \%$.

Given the market SHF-level and the stated overlap with the others stated in equation (10), the threshold rate of return $\left(k^{*}=14.28 \%\right)$ for competence value estimation is found using equation (9bis).

$$
k^{*}=-12.21 \%+1.282 \times 20.66 \%=14.28 \%
$$

The same computation can be repeated for any industry in order to identify specific $k^{*}$ levels ${ }^{4}$.

The corporate performance is good if and only if the total return rate from the company (i.e., the sum of the numerators in equation (2bis) and (2ter)) is greater than (equals to), the resulting $k^{*}$ figure.

$$
k^{*} \leq r^{*}=(r-x)+\frac{p(x+c)}{(1+k)^{t}}
$$

According to equations (11), (12) and (13), the existence of competence value can be supposed if you have a positive residual subtracting the current corporate return (i.e., $[r-x]$, if any ' $x$ ') from $r$.

$$
r^{*}-k^{*}
$$

Accordingly, you may have four qualities of corporate performance:

1 competitive-companies with high returns $(r>k)$ but without long term skill tillage that might affect the persistence of the corporate performance [unsatisfied condition (14)] 
2 competence-based-enterprises with high competence value [satisfied condition (14)] but poor short term performance (i.e., $[r-x]<k$ )

3 vulnerable-firms which destroy value $(r<k)$ but have positive returns, higher than the cost of debt capital only $(r>i>0)$

4 excellent-firms with contribution to the positive gap between mean and median data of the sample because have both goodwill and competence $[r>k$ and condition (14) satisfied].

This is the clusters breakdown for the entire TV-area:

1 competitive (value-creating) companies

- frequency: $42.11 \%$ of the companies included in the sample meet this condition

- current Q-ratio: 1.6049 (the cluster average, computed as $r_{i} / k$ )

- 0.7773 is average Q-ratio of the TV-sample since less than $50 \%$ are competitive firms

2 competence-based enterprises

- frequency: $31.58 \%$ of the companies included in the sample meet this condition

- potential Q-ratio: 8.8990 at the e-completing phase, computed as $[(r+c) / k]$

- current T-ratio: 1.2818 [i.e., proxy estimation of $W_{2} / B V$ based on equation (13)]

3 vulnerable firms (surviving but value-destroyer companies)

- frequency: $20.44 \%$ of the companies included in the sample meet this condition

- current Q-ratio: 0.1293

4 excellent firms (having jointly $Q$ and $T>1$ )

- frequency: $9.56 \%$ of the companies included in the sample meet this condition.

Estimates for any specific industry are reported in Table 3. Some key points emerge in spite of these comprehensive results of the entire TV area:

1 The economic incentive to sustain competence value is dramatically high even in the case of extension of several years of the maturity of the e-pullulating phase. An estimate of the maximum required time-length to capitalise the current 1.60 Q-ratio of the competitive companies to the potential 8.90 Q-ratio embedded in the skilled firms is 13 years (12.83) if computed according to the $14.28 \%$ rate of return. Of course, the probability of success (p) may even affect the required time length; the higher is $\mathrm{p}$, the lower the break-even-t must be. at $30 \%$ probability (the typical probability success ratio of venture) the duration time is reduced to four years (4.40).

2 Competitive corporations (42.11\%) do not overlap to entrepreneurial business $(31.58 \%)$, even in the very competitive TV-district. Only $9.56 \%$ of companies can be included in excellent-firms cluster. This means that $32.55 \%$ corporations $(42.11 \%-9.56 \%)$ are competitive now but do not seem to have long term capability to perpetuate their competitiveness. On the opposite side, $22.02 \%$ (31.58\%-9.56\%) of corporations are competence-based without enough current book returns (maybe they are e-seed). 
3 Out effect generated by the funding activity of vulnerable firms. Capital flows diversion from the $22.02 \%$ competence-based companies missing short-term returns immediately to the $20.44 \%$ vulnerable firms emerges clearly according to the empirical evidence of T-ratio and Q-ratio of the two clusters. Being funded at present, we can suppose that such vulnerable companies showed good Q-ratio standing (i.e., were Basel compliant) at the moment of capital allowance from the banking system, but no controls over the persistency of returns were done as implied in standard financial analysis.

Considering the above depicted role of debt capital in competence value emersion and in SME funding, we conclude that misallocation in banking capital could be reduce by competence value detection, thus removing a real obstacle to complete the entrepreneurial cycle of the corporation (i.e., the long term economic growth) of the entire TV area. On average, the missing value is about 51\% (i.e., 1.28-0.77) of total book values. Should the entrepreneurs be able to complete all the steps of their entrepreneurial cycle, the leverage ratio of these undercapitalised Italian companies would drop dramatically.

Detailed computation at industry level gives further insight. The results clearly reflect how the convergence between the two indicators is never reached. On average, however, one can observe Intato-T-ratio values higher than those of Tobin-Q-ratio. This suggests that not so many business have the capacity to transform the self-competence value in goodwill, meaning that entrepreneurship is not so widely diffused. At the same time, the gap between T-ratio and Q-ratio depicts the opportunity cost of bad practices in credit allowances by Italian banks even in a strongly competitive area such as the TV-district. Moreover, standard Basel methods for credit allowances refer to Q-ratios, thus they suggest to invest more in apparently competitive industries and crunch credits to those having higher opportunities (i.e., wider T-Q spreads).

Table 3 depicts more detailed results of $Q$ and $T$ estimates for different industries. As a general remark, it clearly emerges that very few industries have similar numeric values of $\mathrm{T}$ and $\mathrm{Q}$. This evidence let us conclude that the capital allocation in the TV area is missing selectivity. But this is quite an obvious lemma of the use of bulk analytical tools, since their aim is to revert anything to the means instead of exploiting exceptions (both negative and positive, of course!).

Table 3 Tobin-Q-ratio and Intato-T-ratio found in industries

\begin{tabular}{lcc}
\hline Industry (translation of the original Italian name) & Q-ratio & T-ratio \\
\hline Agriculture and hunting services, forestry & 0.4382 & 1.3566 \\
Food and drink & 1.2410 & 1.2299 \\
Manufacture of textiles & 0.4131 & 1.1274 \\
Manufacture of clothing, dyeing, tanning fur & 0.8605 & 1.3579 \\
Manufacture of leather goods made of wood, cork, straw & 0.5577 & 1.2288 \\
Manufacture of wood, cork, straw & 0.5346 & 1.0293 \\
Manufacture of paper and paper products & 0.6065 & 0.9537 \\
Publishing, printing and reproduction of recorded media & 0.9120 & 1.1209 \\
\hline
\end{tabular}

Source: Our processing of data from the above data sources and algorithms from Teofilo Intato Foundation 
Table 3 Tobin-Q-ratio and Intato-T-ratio found in industries (continued)

\begin{tabular}{llc}
\hline Industry (translation of the original Italian name) & Q-ratio & T-ratio \\
\hline Manufacture of chemicals and artificial synthetic fibres and & 1.5666 & 1.3534 \\
Manufacture of rubber and plastic products & 0.8177 & 1.2594 \\
Manufacture of other non-metallic mineral processing & 0.5123 & 1.3472 \\
Metallurgy - manufacture and processing of metal products & 0.9777 & 1.2198 \\
except machinery and equipment & & \\
Manufacture of computers and electronic and optical products, & 0.6858 & 1.0578 \\
electrical appliances, etc. & & \\
Manufacture of electrical and non-electric domestic appliances & 0.8497 & 0.9332 \\
Manufacture of machinery and equipment nec & 0.7140 & 1.2818 \\
Manufacture of motor vehicles, trailers and semitrailers & 0.9439 & 1.2593 \\
Manufacture of other transport equipment & 0.4026 & 0.8536 \\
Manufacture of furniture & 0.7867 & 1.2205 \\
Other manufacturing & 1.0267 & 1.3729 \\
Building societies & 0.9928 & 1.2014 \\
Trade, maintenance and repair of motor vehicles and motorcycles & 1.0295 & 1.3755 \\
Commerce wholesale and commission trade, motor vehicles and & 0.9132 & 1.2593 \\
motorcycles & & \\
Retail (excluding motor vehicles and motorcycles), repair of & 0.6306 & 0.8767 \\
personal and household goods land transportation, pipeline & & \\
transport, storage and auxiliary transport activities & & \\
Hotels and restaurants activities & 0.2677 & 1.2891 \\
Computer and related activities & 1.5651 & 1.4825 \\
Real estate & 0.6301 & 1.4380 \\
Professional services & 1.2434 & 1.5666 \\
Recreational cultural and sports & 0.3396 & $\mathrm{~N} . \mathrm{A}$. \\
Treviso's District as a total & $\mathbf{0 . 7 7 7 3}$ & $\mathbf{1 . 2 8 1 8}$ \\
\hline
\end{tabular}

Source: Our processing of data from the above data sources and algorithms from Teofilo Intato Foundation

Analysis of the data in Table 4 clearly confirms that there is no perfect overlap between competitive and skilled firms, implying that even the frequency of Q-ratio $>1$ and the T-ratio $>1$ does not converge. This is particularly consistent with the hypothesis of incomplete markets, but - at the same time - is proof that entrepreneurial value discovery require industries to be analysed more carefully using non-obvious methods. This is exactly the opposite of Basel approaches that prefers to adopt standard bulk techniques in financial analysis in search of industries with only high level of (short term) goodwill instead than (long term) competence value emersion. This approach avoids considering that in the long run the competition only tends to reduce operating margins without opportunity for their recovery, as given by competence emersion. According to these standard approaches, capital flows have lower processing costs but prefer pro-cyclical allocation to reduce opportunities. 
Table 4 Frequency of competitive firms and entrepreneurial firms

\begin{tabular}{|c|c|c|}
\hline Industry (translation of the original Italian name) & $\begin{array}{c}\text { Frequency of } \\
Q>1 \text { firms }\end{array}$ & $\begin{array}{c}\text { Frequency of } \\
T>1 \text { firms }\end{array}$ \\
\hline Agriculture and hunting services, forestry & $32.92 \%$ & $19.72 \%$ \\
\hline Food and drink & $56.68 \%$ & $18.04 \%$ \\
\hline Manufacture of textiles & $24.16 \%$ & $36.26 \%$ \\
\hline Manufacture of clothing, dyeing, tanning fur & $45.40 \%$ & $36.51 \%$ \\
\hline Manufacture of leather goods made of wood, cork, straw & $27.51 \%$ & $56.23 \%$ \\
\hline Manufacture of wood, cork, straw & $28.93 \%$ & $31.57 \%$ \\
\hline Manufacture of paper and paper products & $28.97 \%$ & $42.88 \%$ \\
\hline Publishing, printing and reproduction of recorded media & $46.43 \%$ & $37.05 \%$ \\
\hline Manufacture of chemicals and artificial synthetic fibres and & $63.84 \%$ & $25.93 \%$ \\
\hline Manufacture of rubber and plastic products & $43.37 \%$ & $32.67 \%$ \\
\hline Manufacture of other non-metallic mineral processing & $24.96 \%$ & $57.58 \%$ \\
\hline $\begin{array}{l}\text { Metallurgy - manufacture and processing of metal products } \\
\text { except machinery and equipment }\end{array}$ & $49.14 \%$ & $39.23 \%$ \\
\hline $\begin{array}{l}\text { Manufacture of computers and electronic and optical products, } \\
\text { electrical appliances, etc. }\end{array}$ & $37.26 \%$ & $30.06 \%$ \\
\hline Manufacture of electrical and non-electric domestic appliances & $46.48 \%$ & $6.98 \%$ \\
\hline Manufacture of machinery and equipment nec & $37.35 \%$ & $48.55 \%$ \\
\hline Manufacture of motor vehicles, trailers and semitrailers & $47.91 \%$ & $34.61 \%$ \\
\hline Manufacture of other transport equipment & $25.79 \%$ & $15.43 \%$ \\
\hline Manufacture of furniture & $40.94 \%$ & $42.87 \%$ \\
\hline Other manufacturing & $51.00 \%$ & $43.43 \%$ \\
\hline Building societies & $49.80 \%$ & $14.13 \%$ \\
\hline Trade, maintenance and repair of motor vehicles and motorcycles & $50.92 \%$ & $32.06 \%$ \\
\hline $\begin{array}{l}\text { Commerce wholesale and commission trade, motor vehicles and } \\
\text { motorcycles }\end{array}$ & $47.79 \%$ & $13.98 \%$ \\
\hline $\begin{array}{l}\text { Retail (excluding motor vehicles and motorcycles), repair of } \\
\text { personal and household goods land transportation, pipeline } \\
\text { transport, storage and auxiliary transport activities }\end{array}$ & $37.30 \%$ & $12.04 \%$ \\
\hline Hotels and restaurants activities & $27.25 \%$ & $29.47 \%$ \\
\hline Computer and related activities & $62.53 \%$ & $32.91 \%$ \\
\hline Real estate & $36.98 \%$ & $33.04 \%$ \\
\hline Professional services & $55.29 \%$ & $30.41 \%$ \\
\hline Recreational cultural and sports & $33.33 \%$ & N.A. \\
\hline Treviso's District as a total & $42.11 \%$ & $31.58 \%$ \\
\hline
\end{tabular}

Source: Our processing of data from the above data sources and algorithms from Teofilo Intato Foundation 


\section{Concluding remarks}

A possible methodology of competence value estimation has been presented supposing an incomplete financial market context. Such a method is based on a three stage life cycle of entrepreneurial behaviour. The method clearly shows strong differences between goodwill generation and competence widespread.

High value-to-price ratios of incomplete financial markets are terrific economic incentives to let value emerge. The progressive marketability of competence value could contribute more effectively to the financing of the process of accumulation of skills. Hence, they should be a good challenge for entrepreneurs to reap the financial resources they require. But, at the same time, their price-discovery mechanisms are all biased by the absence of pairing groups for value benchmarking, an exasperating constraint for entrepreneurial finance practices. This is exactly why standard financial analysis systems fails to measure the competence value, thus avoiding to consider it in the capital allowances decisions of the intermediaries. Currently, neither the book values nor the market values can appreciate them: the former detects the capital-quotas only and the latter is usually missed due to market incompleteness. Contrarian to the standard 'Basel' approaches for SMEs financing, debt could be superior in the phase of competence spreading: debt can contribute to complete financial markets by riding the competence value.

Debt funding with strong covenants can resolve agency problems which arise from the abandonment option that the entrepreneur may always exercise. The return-to-risk ratio of a company consequently drops. However, these empirical data from the Treviso's District suggest some final considerations:

1 Incentives in the traditional industries that do not support the transformation of skills into market value are likely to support business initiatives that generate excess returns in the short term, but which are unable to sustain long term performance. This could contribute to explain the lower growth ratio of Italian SMEs (and economics).

2 The application of criteria for determining the credit allowances based only on return-to-risk compatible with the neo-classical theory of finance is likely to encourage the formation of values that might emphasise long-term instability of the system because (debt) capital flow is given when competitive factor is on the top.

3 It remains an open question as to whether having several financial solutions could resolve the emergence of higher potential values.

This will be the topic of our future investigations. At present we can state that the gap between the indicators and economic space has not yet filled in terms of selectivity in its financing. This gap may dramatically increase in case of application of Basel-3 agreement without considering value discovery opportunities given by entrepreneurial finance. This gap can only be resolved with the formation of qualified professionals (especially in corporate finance) equipped with reliable tools such as the ones presented here. This is a challenge for both academics and practitioners. The Treviso's experience can be an example! 


\section{Acknowledgements}

Special thanks to Prof. Arie Melnik from University of Haifa for the very useful comments and insights he gave to the first draft of the paper during the 2011 Annual Meeting of the Academy of entrepreneurial finance in UCLA, Los Angeles (CA). Huge gratitude and thankfulness to the anonymous referees of the journal: their comments strongly contributed to upgrade the paper. Thanks for comments and top scientific support even to:

1 Prof. Rachel Price-Kreitz (Ecole de Management, Strasbourg), a fantastic English proof-reader

2 Prof. A. Moro (University ofLeicester)

3 Proff. G. Bertinetti and A. Pontiggia (Ca' Foscari University, Venice-Campus)

4 Proff. G. Corò and L. Pelizzon (Ca' Foscari University, Treviso-Campus)

5 Dr. Elisabetta Borghesani (SICRA-Group, London) and Dr. Fabio Bortoli (BSI, Lugano)

6 Last-but-not-least, the ten years, never ending, encouragements from Agostino Tres and Pierluigi Svaluto (Teofilo Intato Found. Promoter Committee, Lentiai, Belluno).

All responsibilities remains to the author only, who is fully responsible for the contents of the paper.

I would like to thank the promoting committee of the Teofilo Intato Foundation for the wide support in my research activities since 2004 and a special thanks to all the junior researchers who contribute to the research activities at the (Progetto-zero-nove) 'P09 Research Centre' to develop and widespread the use of the method. As per this paper I am indebted to Elisa Daniotti for data mining, treatment and computations and to Elisa Bisconti and Marta Tres for research support. But even more to Teofilo Intato himself for the insights given with his life.

\section{References}

Allen, D. and Gale, F. (1994) Financial Innovation and Risk Sharing, MIT Press, Cambridge, Massachusetts.

Arrow, K.J. (1971) Theory of Risk Bearing, Makham, Chicago.

Baumol, W.J. (1968) 'Entrepreneurship in economic theory', American Economic Review, Vol. 58, No. 2, pp.64-71.

Baumol, W.J. (1986) 'Entrepreneurship and a century of growth', Journal of Business Venturing, Vol. 1, No. 2, pp.141-145.

Baumol, W.J. (1993) 'Formal entrepreneurship theory in economics: existence and bounds', Journal of Business Venturing, Vol. 8, No. 3, pp.197-210.

Ben-David, I., Graham, J. and Harvey, C. (2007) Managerial Overconfidence and Corporate Policies, NBER Working Paper, No. 13711.

Bini, M. and Guatri, L. (2003) Impairment, Egea, Milano. 
Bodie, Z., Kane, A. and Markus, A.J. (2014) Investments, 10th ed., McGraw-Hill, New York.

Brav, O. (2009) 'Access to capital, capital structure, and the funding of the firm', The Journal of Finance, Vol. 64, No. 1, pp.263-308.

Busenitz, L. (1999) 'Entrepreneurial risk and strategic decision making: it's a matter of perspective', Journal of Applied Behavioral Science, Vol. 35, No. 3, pp.325-340.

Chen, C.R. and Steiner, T.L. (2000) 'Tobin's Q, managerial ownership, and analyst coverage', Journal of Economics and Business, Vol. 52, pp.365-382.

Chen, Q. and Jiang, W. (2006) 'Analysts' weighting of private and public information', Review of Financial Studies, Vol. 19, No. 1, pp.319-355.

Cooper, A.C., William, C.D. and Carolyn, Y.W. (1988) 'Entrepreneurs' perceived chances for success', Journal of Business Venturing, Vol. 3, No. 2, pp.97-108.

Copeland, T., Koller, T. and Murrin, J. (1995) Valuation. Measuring and Managing the Value of Companies, 1 st ed., Wiley \& Sons, New York.

Covin, J.G. and Slevin, D.P. (1991) 'A conceptual model of entrepreneurship as firm behaviour', Entrepreneurship Theory and Practice, Vol. 16, No. 1, pp.7-25.

Debreu, G. (1959) Theory of Value. An Axiomatic Analysis of Economic Equilibrium, Yale University Press, New Haven and London.

Diamond, D. (1991) 'Monitoring and reputation: the choice between bank loans and directly placed debt', Journal of Political Economy, Vol. 99, No. 4, pp.689-721.

Fama, E.F. and MacBeth, J.D. (1973) 'Risk, return, and equilibrium: empirical tests', Journal of Political Economy, Vol. 81, No. 3, pp.607-636.

Faulkender, M. and Petersen, M.A. (2006) 'Does the source of capital affect capital structure?', Review of Financial Studies, Vol. 19, No. 1, pp.45-79.

Fernandez, P., Aguirreamalloa, J. and Avendaño, L.C. (2011) 'Market risk premium used in 56 countries in 2011: a survey with 6,014 answers', 25 April, SSRN [online] http://ssrn.com/ abstract=1822182 or http://dx.doi.org/10.2139/ssrn.1822182 (accessed September 2013).

Gardenal, G. (2010) Applied Topics in Financial Agents' Behavior, Doctoral dissertation, Venice.

Griffin, D.W. and Varey, C.A. (1996) 'Towards a consensus on overconfidence', Organizational Behavior and Human Decision Processes, Vol. 65, No. 3, pp.227-231.

Hilary, G. and Menzly, L. (2006) 'Does past success lead analysts to become overconfident?', Management Science, Vol. 52, No. 4, pp.489-500.

Hiller, N.J. and Hambrick, D.C. (2005) 'Conceptualizing executive hubris: the role of (hyper) core self-evaluations in strategic decision-making', Strategic Management Journal, Vol. 26, No. 4, pp.297-319

Hisrich, R.D. and Kearney, C. (2012) Corporate Entrepreneurship, McGraw-Hill, New York.

Kerins, F., Kiholm Smith, J. and Smith, R. (2004) 'Opportunity cost of capital for venture capital investors and entrepreneurs', The Journal of Financial and Quantitative Analysis, June, Vol. 39, No. 2, pp.385-405.

Kilby, P. (1971) Entrepreneurship and Economic Development, The Free Press, New York.

Klayman, J., Soll, J.B., González-Vallejo, C., Barlas, S. (1999) 'Overconfidence: it depends on how, what, and whom you ask', Organizational Behavior and Human Decision Processes, Vol. 79, No. 3, pp.216-247.

Latham, M. (1985) Defining Capital Market Efficiency, Finance Working Papers 150, Institute for Business and Economic Research, University of California, Berkeley, April.

Leibowitz, M.L. (1995) Return Targets and Shortfall Risk: Studies in Strategic Asset Allocation, McGraw-Hill Company, New York.

Lintner, J. (1965) 'The valuation of risk assets and the selection of risky investments in stock portfolios and capital budgets', The Review of Economics and Statistics, Vol. 47, No. 1, pp.13-37. 
Malmendier, U. and Tate, G. (2008) 'Burak G, financial expertise of directors', Journal of Financial Economics, Vol. 88, No. 2, pp.323-354.

Mantovani, G.M. (1998) Rischio e valore dell'impresa, Egea, Milano.

Mantovani, G.M. (2003) 'Premi di maggioranza: distorsioni di mercato o emersioni di competenze?', Contabilità, Finanza e Controllo, No. 6, pp.646-653.

Mantovani, G.M. (2012) 'The information risk drivers. A long-term analysis to support a risk premia modelling', Quarterly Journal of Finance and Accounting, Vol. 50, No. 1, pp.145-199.

Massari, M. and Zanetti, L. (2004) Valutazione Finanziaria, McGraw-Hill, Milano.

Mehra, R. and Prescott, E.C. (1985) ‘The equity premium: a puzzle', Journal Monetary Economics, Vol. 15, No. 1, pp.145-161.

Merton, R.C. (1990) Continuous-Time Finance, Blackwell, Oxford.

Modigliani, F. and Miller, M.H. (1958) 'The cost of capital, corporation finance and the theory of investment', American Economic Review, Vol. 48, No. 3, pp.261-297.

Nevitt, P.K. (1988) Project Finance, Laterza Editori, Bari.

Orser, B., Cedzynski, M. and Roland, T. (2007) 'Modelling owner experience: linking theory and practice', Journal of Small Business and Entrepreneurship, Vol. 20, No. 4, pp.387-408.

Rajan, R.G. and Zingales, L. (1995) 'What do we know about the capital structure? Some evidence from international data', The Journal of Finance, Vol. 50, No. 5, pp.1421-1460.

Reuber, A. and Fischer, E. (1999) 'Understanding the consequences of founders' experience', Journal of Small Business Management, Vol. 37, No. 2, pp.30-46.

Robichek, A.A. and Myers, S.C. (1965) Optimal Financing Decisions, Prentice-Hall, Inc. Englewood Cliffs, NJ.

Ross, S. (2002) A Neoclassical Look at Behavioral Finance; Closed end Funds, The Princeton Lectures in Finance III, Working Paper, September.

Rubinstein, M. (1975) 'Securities market efficiency in an Arrow-Debreu economy', American Economic Review, December, Vol. 65, pp.812-824.

Rullani, E. (2004) Economia della conoscenza: creatività e valore nel capitalismo delle reti, Carocci Editore, Rome.

Salim, R.A. (2005) 'Modelling entrepreneurship in small-scale enterprises', Applied Economics Letters, Vol. 12, pp.51-57.

Schwartz, E. and Trigeorgis, L. (2004) Real Options and Investment Under Uncertainty, MIT Press, Boston.

Tobin, J. (1958) 'Liquidity preference and behavior toward risk', Review of Economic Studies, February, pp.65-86.

Unicredit Banca (2004) Mediocredito Italiano, I covenant di bilancio nei finanziamenti a medio e lungo termine, Bancaria, Rome.

Williamson, O.E. and Masten, E.S. (1999) The Economics of Transaction Costs, Elgar, Cheltenham, UK and Northampton, MA.

Yazdipour, R. (2011) Advances in Entrepreneurial Finance (with application from Behavioural Finance and Economics), Springer, New York.

Zahra, S.A. (1991) 'Predictors and financial outcomes of corporate entrepreneurship: an exploratory study', Journal of Business Venturing, Vol. 6, No. 4, pp.259-285.

Zahra, S.A. and Covin, J. (1995) 'Contextual influence on the corporate entrepreneurship performance relationship: a longitudinal analysis', Journal of Business Venturing, Vol. 10, No. 1, pp.43-58. 


\section{Notes}

1 Still a steady state company is supposed, to make easier to understand and to continue the previous exposition.

2 Here further the application of the original Intato-method is transparently illustrated as it was developed at industry-level, but any responsibility for unclearness is due to the author. We thank the trustees of the foundation to allow us of the full use of industry-level formulas in this paper.

3 This is indeed the inner difference in the application of the method at industry level for an ex-post verification. In ex-ante esteem you can anyway consider the mean reversion of corporate that can be useful even to apply the method at corporate level.

4 Transforming the market shortfall $(-12.21 \%)$ into an threshold return $(+14.28 \%)$ is useful for the application of the formula at industry level. At corporate level, practice suggests to use the shortfall, being easier to estimate the competence value through the analysis of the true possibility of the company to generate returns higher than market shortfall $(-12.21 \%)$ with a $90 \%$ confidence. This being the case, the persistency of returns is supposed. 